\title{
IDENTITETA KOT MODNA MUHA? ODSTIRANJE KULIS POPULARNOSTI SKOZI PRIMER BOSANSKO-HERCEGOVSKE UDOMAĆITVE BRUCEA LEEJA
}

Ključne besede: identifikacijski procesi, (nacionalna) identiteta, konstrukcija 'Drugih', nacionalna kultura, popularna kultura, Balkan, Bosna in Hercegovina, Bruce Lee

Ni si mogoče zatiskati oči pred dejstvom, da je turbulentni prehod iz 20. $\mathrm{v} 21$. stoletje potisnil etnologijo in kulturno antropologijo v trden objem, sicer že desetletja navzočega 'tematskega trenda'. Tako posamezni glasovi opredeljujejo sodobno etnologijo in kulturno antropologijo kratko malo kot disciplino, ki kaže precejšnje, morebiti celo obsesivno zanimanje za identifikacijske procese in kulturne identitete. Kljub dejstvu, da se uspešnice v skladu $z$ utečeno navado dotaknejo slovenskih tal nekoliko pozno, se je potapljanje $\mathrm{v}$ globine identitet precej hitro uveljavilo $\mathrm{v}$ raziskovalnem zanimanju tudi pri nas ter s presenetljivim zagonom še zdaj polni strani mnogih monografij in publikacij. Kljub mnogim delom, ki so se na Slovenskem priključila dekonstruiranju esencialističnih pojmovanj identitete (glej Brumen, 2000; Muršič, 1997; Repič, 2005), še vedno lahko zasledimo obravnave identitetnih procesov, ki zavračajo kontrastno oz. relacijsko naravo identitet ter trmasto vztrajajo na njihovi nespremenljivosti in dokončnosti. $\mathrm{V}$ tovrstnih pojmovanjih je identiteta lastnina in atribut posameznika ali skupine, ki se pojavlja in izginja (Muršič, 1997, 225-226). Tako denimo v Slovenskem etnološkem leksikonu, ki naj bi "povzel poglavitna spoznanja o slovenski etnologiji« (Baš, 2004, VI), beremo, da je identiteta »nezamenljiv ali poseben skupek lastnosti, načinov ravnanja, mišljenja in doživljanja, v katerih posameznik v svojem življenju prepoznava sebe ... in druge ali se 
odloča za pripadnost določeni skupini, narodu ali živi določeno kulturo« (Baš, 2004, 174).

Živahne sodobne polemike o identitetnih procesih nam vsekakor zastavljajo vprašanje, kje pravzaprav tiči magična privlačnost identitete? V njeni naravi ali $v$ očeh opazovalca?

Samoniklost nedvomno ni pot, po kateri na svet prihajajo pomeni; ti neizogibno zahtevajo stvarnika, ki je vselej umeščen $\mathrm{v}$ poseben čas in prostor. Vsekakor bi bilo nesmiselno in obžalovanja vredno, če bi tudi po plodnih razkritjih postmodernističnega teoretiziranja zanemarjali vplive okolja, življenjskih razmer in obremenjujočih spodbud ideoloških aparatov države, skratka celotnega kompleksnega okvira, ko gre za obravnavo naših lastnih zanimanj in vodil. Tudi manjši med množico koncentričnih krogov, ki nas obdajajo, posedujejo (bolj ali manj) prepričljivo moč, saj denimo dominantne smernice $\mathrm{v}$ disciplini niso zgolj nepomembni in preslišani pozivi, temveč mnogokrat kažipoti, ki nas usmerjajo in vodijo. V preteklosti so etnologi in kulturni antropologi vdano sledili kultu objektivnosti, kar je sicer hvalevredno početje, a vendar le $\mathrm{v}$ primeru, ko ni združeno $\mathrm{z}$ naivno zagledanostjo v poslanstvo 'odkrivanja Resnice'. Če bi se danes drznili izolirati iz obstoječega družbenega okvira, bi si podelili sicer všečno, a neetično pozicijo edinih pravovernih tolmačev svetovnega dogajanja in življenja, hkrati pa bi bilo tovrstno zanemarjanje korenite preobrazbe discipline velik korak nazaj, ki vodi v varno zavetje akademske večvrednosti in napuha. Vse kaže, da se identitetam ni mogoče povsem ogniti; če se že odločimo za njihovo zavestno ignoranco $\mathrm{v}$ procesu raziskovanja, se identiteta pišočega začne, tudi brez privolitve, zrcaliti $\mathrm{v}$ njegovih interpretacijah in ubeseditvah.

Množica naveličanih obrazov in precej glasno negodovanje posameznih raziskovalcev in raziskovalk nad popularnostjo identitete nikakor niso prepričljivi argumenti za opustitev problematiziranja identifikacijskih procesov. Prav nasprotno. Prizadetost in obrambna poza, ki jo zavzemajo prenekateri strokovnjaki, delujoči v disciplinah, znotraj katerih so razkrili že mnoge pasti obstoječih kulturnih konstruktov, krepi možnosti radovednosti, da nas zapelje in pahne v naročje novih vprašanj. Nikakor torej ne gre za zanemarljiv 'fenomen', ki neupravičeno obremenjuje antropološke oziroma etnološke sfere. Zlasti v okvirih, $\mathrm{v}$ katerih je usidrana vladavina strupenega 
nacionalizma, kjer si je nacionalna identiteta zagotovila dominantni status, kjer je ta vseskozi zlorabljena $\mathrm{v}$ politični, narodnobuditeljski retoriki in kjer se izpostavlja kot najvišja vrednota, ki jo je treba predano in zavzeto ohranjati pri življenju, pa četudi na račun življenj njenih nosilcev, je obračanje pogleda proč od identitet ne le poveden izraz zavestne ignorance in ubogljivega prikimavanja avtoritativnim pridigarjem, ki so razkrili in izrabili priročnost nacionalizma za doseganje lastnih ciljev, temveč mnogokrat tudi pogubno dejanje z daljnosežnimi (tragičnimi) posledicami. Šolski primer, ki pa je samo eno izmed mnogih žarišč maničnih besedičenj o ogroženosti nacionalnih identitet, je Republika Bosna in Hercegovina, ki je že nekaj časa in zatorej tudi tu v središču mojega zanimanja in od koder črpam empirične primere za precej teoretsko naravnano narativno popotovanje.

\section{O tegobah portretiranja identitete}

Za nacionalizem je jasno, da gre za ideologijo oziroma »ideološko gibanje, katerega cilj je doseči ali ohraniti avtonomijo, enotnost in identiteto družbene skupine, za katero velja, da tvori nacijo «(Smith, 1998, 85), stvar pri nacionalni identiteti pa je precej bolj zapletena. V vsakdanjem govoru je sicer nacionalna identiteta pragmatično dojeta kot nekaj samoumevnega, nekaj, kar naj bi posameznik posedoval, ohranjal ali zbegano iskal (Billig, $1995,7)$. Pogovori z naključnimi sogovorniki, ki so se v zadnjih letih zgodili kar mimogrede, brez predhodne namenske konstrukcije 'terena', razkrivajo, da identiteto posamezniki razumejo kot vrednoto, ki naj ima status nedotakljivosti, kajti identiteta naj bi bila pogoj za duhovno bogastvo posameznika in skupnosti. V splošnem se torej identiteta omeji na neopredeljivo mešanico nacionalne kulture in 'duha naroda'. Isto pojmovanje identitete $\mathrm{v}$ sodobnem humanističnem in družboslovnem besednjaku po razkritju in zavračanju zmotnega prepričanja o identiteti kot reificirani entiteti seveda ne zdrži. V nasprotju z nacionalno ideologijo, etnologi in antropologi množicam ne zmorejo ponuditi všečnega, spevnega in lahko razumljivega odgovora na zastavljeno vprašanje. Kajti vsaka identiteta je v svoji naravi izredno dinamična, gibljiva, nikoli dokončno formulirana, začasna, situacijska in zatorej izmuzljiva. To spoznanje po mnenju Zygmunta Baumana (1992) 
močno nasprotuje prepričanjem moderne dobe, ki se je vztrajno trudila konstruirati identiteto in jo obdržati v strogo zamejenem ter obvladljivem kalupu. Na neprimernost fiksacije in neobvladljivost identitete opozarja tudi Stuart Hall, ki meni, »da je identifikacija dejansko eden od najslabše razumljenih konceptov«, in dodaja, da jo je zmotno obravnavati kot objekt, saj je v resnici - proces. Zato ugotavlja, da je bolj korektno in upravičeno govoriti o identifikaciji, torej procesu konstantnega (samo)prepoznavanja, kot pa o statični, enkrat za vselej oblikovani 'lastnini' posameznika, torej identiteti (Hall, 2000, 16). Podobno kot kulture (kakor ugotavlja Clifford, 1986 ) identitete, (če si na tem mestu izprosim pomoč (sicer vselej problematične) personifikacije), zaznamuje neučakanost, kajti te še zdaleč niso pripravljene zavzeti trdne poze, ki bi omogočala etnologovi/antropologovi roki, da izriše njihov portret. Končni produkti tovrstnih poskusov upodabljanj so zato nemalokrat motne in meglene stvaritve. A vendarle moteče zameglitve, motnje in opazne hibe v artikulaciji videnega in doživetega precej spretno zakrivamo in bolj ali manj spretno prevajamo v lepo zvenečo in kar se da koherentno pripoved. Pri tem pa se je seveda vselej treba zavedati, da identitete niso nič bolj gibljive kot družbeno okolje oziroma okvir, znotraj katerega obstajajo (Kempny, 2002, 10).

Razumevanje identitete je torej jetnik težko obvladljive kaotičnosti in zatorej lahko le pritrdimo Dunji Rihtman-Auguštin, ki modro ugotavlja, da je mnogo lažje v teoriji razumeti tovrstne spremembe identitet in jih utemeljevati z njihovo naravnostjo ali neizogibnostjo, kakor da bi jih zlahka sprejeli v naših lastnih življenjih (Rihtman-Auguštin, 2000, 229), v katerih se z vso močjo oklepamo predvidljivosti in všečne urejenosti. Svet je namreč precej kompleksnejši, kot ga želimo videti, saj neustavljivi vrtinci sprememb niso nikoli pritegnili pretiranega občudovanja in odobravanja. Mučna konfuznost pa se pri obravnavi identitet ne konča prav kmalu.

Dodatno zmedo v obstoječi labirint prispeva dejstvo, da vsak posameznik poseduje (in obenem vztrajno preoblikuje) več identitet, ki se med seboj prepletajo in zapletajo (glej Brumen, 2000; Kalapoš, 1996). Spoznanje, da identitete ni moč povsem neodvisno 'secirati', je vodilo etnologe/antropologe $\mathrm{v}$ intenzivno ukvarjanje $\mathrm{z}$ njihovo večplastnostjo; vendar so se osredotočali zlasti na odnos med nacionalno in regionalno ali pač spolno identiteto, pri tem pa so med drugim pogosto spregledali simultan obstoj 
dveh ali celo več nacionalnih identitet. Toda njihovega soobstoja (tudi sožitja nacionalne in državljanske identitete) v sodobni, globalizirajoči se družbi pravzaprav ni mogoče prezreti, kar morebiti najbolj povedno izpričujejo sodobne raziskave migracij in življenja znotraj transnacionalnih skupnosti. To nam navsezadnje dokazuje tudi zgodba naše lastne preteklosti, denimo jugoslovanski primer, saj občutje pripadnosti določenemu narodu, naj si gre za Hrvate, Srbe, Slovence, Makedonce ..., ni (vselej) izključevalo čutenja jugoslovanstva kot svojega. Ekskluzivistične idelogije namenoma trmasto zavračajo vzporedne lojalnosti in pripadnosti nacionalnim kolektivom, pa četudi je jasno, da poistovetenje $\mathrm{z}$ določeno skupino ne zahteva nujno odpovedovanja drugemu delu svoje identitete (Fonda, 2003, 113). Kakor ugotavlja Stuart Hall, obstajajo ljudje, ki pripadajo več svetovom, in ti vseskozi odkrivajo načine, kako $\mathrm{v}$ istem trenutku »biti enak kot in obenem drugačen $o d$ « drugih (po Inda in Rosaldo, 2002, 19). Tako je za posameznike, ki so odraščali v 'mešanem zakonu,', ali denimo pripadnika etnične manjšine življenje po rigidnih, ukalupljenih, izključujočih in enostranskih nacionalnih težnjah v resnici nepredstavljivo. Okolje, ki se ne le zaveda lastne multikulturalnosti, temveč jo tudi spoštuje in pričakuje, od posameznika pogosto izsili premišljevanje o smiselnost meja, ki so za nacionalno ideologijo predmet globoke religioznosti.

Primer Bosne in Hercegovine, predvsem njenega življenja v nedavni preteklosti, ponuja poveden dokaz, ki priča o obstoju prepletajočih se nacionalnih identitet. V državi na Balkanu, ki jo je tragična polpretekla zgodovina, s katero so številni gledalci pred televizijskimi ekrani urili otopelost pred srhljivimi grozotami sodobnosti, potisnila na medijski oder in zapisala na seznam prepoznavnih, je bilo mogoče biti Bošnjak (musliman), Hrvat (katolik) in Srb (pravoslavec) na bosansko-hercegovski način oziroma biti (in se počutiti) tudi Bosanec in Hercegovec. (Po)vojno stanje pa je poseglo po etničnem čiščenju ne le prostora, temveč tudi kulture in identitete $\mathrm{z}$ načrtnim brisanjem pridevnika bosansko-hercegovski, kot da bi obstajala sramota pred nekdanjim sožitjem nacionalnih identitet. Seveda ni mogoče

1 'Mešani zakon' namenoma postavljam $\mathrm{v}$ narekovaje, kajti v resnici »mešani zakoni niso nič bolj 'mešani' od drugih zakonov« (Walton in Warren, 1994, 7). Sam izraz je zgledna ilustracija zagledanosti v predvidljive kategorije, ki so le videti čiste, kajti v neoporečne odtenke jih obarvajo naše usmerjane percepcije. 
spregledati, da se avtorji sodobnih razprav o odnosih med narodi, živečimi v Bosni in Hercegovini, nemalokrat zapletejo v mreže skrajnosti; tako se podajajo ali v demonizacijo ali pač $\mathrm{v}$ drugi ekstrem - idealizacijo odnosov med bosansko-hercegovskim prebivalstvom - in ob zazrtosti v kolektive pogosto spregledajo unikatnost odnosov, ki so produkt interakcije med posamezniki. Dejstvo je, da je med skrajnima točkama dolga pot, in prav ta je prizorišče, na katerem se odvijajo identifikacijski procesi. Pa vendar, ideal nacionalnih držav vztrajno zahteva brezhibno 'čisto' kulturo in identiteto. Gre za vzor, ki mu sledijo tudi na Balkanu, in sicer med drugim uporabljajo znan in nadvse učinkovit mehanizem zlorabljanja preteklosti, v katerem ima častno mesto tudi kolektivna amnezija. Republiko Bosno in Hercegovino zdaj naseljuje precej zavednih Bošnjakov, Hrvatov in Srbov, ${ }^{2}$ majhno število Bosancev in Hercegovcev in le peščica posameznikov, ki skušajo s trudom uskladiti razdvojene nacionalne identitete.

Brez temeljite raziskave je sicer težko odločno potrditi, vendar lahko vsaj spekulativno domnevamo, da je dolgo navzoče zanemarjanje sočasnega obstoja več nacionalnih identitet posledica nezmožnosti znanstvenikov, da se otresejo edinstvenega nacionalnega pečata. Zaradi svoje izključujoče nacionalne identitete in pozicije gledišča - 'iz sebe' (ki se je mimogrede v mnogih raziskavah izkazala za učinkovito izhodišče) - jim je empatija ostala nedosegljiva. Zato pravzaprav ne preseneča, da o čereh nacionalizma in konfuznosti nacionalne identitete danes najbolj glasno razpravljajo zlasti prebivalci prostora 'vmesnosti' (glej Bhabha, 1996), ki imajo v avtobiografiji zapisano izkušnjo domovanja med dvema nacionalnima identitetama, kjer vladata neusklajenost in zagrizena tekmovalnost identifikacijskih sidrišč. Ti so $\mathrm{v}$ svetu, $\mathrm{v}$ katerem nacionalna identiteta $\mathrm{v}$ premnogih okvirih dominira, prisiljeni vselej prizpraševati lastno identiteto in odgovarjati na vprašanja o pripadnosti, ki ne dopuščajo povsem svobodnih odgovorov. Zastavljena vprašanja namreč vsiljujejo ustaljene možnosti; zahtevajo od-

2 Absurdno je, da ko zavedni bosansko-hercegovski Hrvati in Srbi stopijo v stik z državo, ki jo sami poimenujejo kot domovino, se pravi Republiko Hrvaško ali Srbijo in Črno goro, kjer jih 'avtohtoni' prebivalci gledajo z nezaupanjem in kot 'Druge', se njihove iluzije razblinijo. Ob tem se močno zamajejo tudi temelji njihove identitete. Denimo na Hrvaškem, morebiti najbolj prav v hrvaški prestolnici, je Hercegovec izjemno huda žalitev, celo psovka. O odnosu do Hercegovcev na Hrvaškem podrobno piše Dunja Rihtman-Auguštin (2000), o njihovem grenkem razočaranju nad 'domovino' Hrvaško pa Ivan Lovrenović (2002). 
govor, utemeljen na ekskluzivnih kategorijah, še zlasti takrat, ko teče beseda o nacionalni pripadnosti. $V$ resnici gre za zelo enostavno formulo: otrok armenskih staršev - zatorej Armenec, rojen v ZDA - zatorej Američan ... Profesor politolgije, Ronald Grigor Suny, denimo ni ne eno ne drugo, ampak hkrati oboje, zato kot mnogi drugi priznava zgolj kategorije samoumeščanja in »ostaja tujec ... v svoji rojstni deželi«, kar nemalokrat ni najprijetnejši status, pa vendar je, kakor pravi, prav ta pozicija najboljše (nikakor pa ne edino) izhodišče, ki posamezniku omogoča, da "pogleda onkraj političnih omejitev, ki nam jih ponuja sodobnost« (Suny, 1999, 56). Pri zanemarjanju večplastnosti identitet in njene hibridne narave je odločilno vlogo odigralo tudi dejstvo, da so raziskovalce omejevale dolgo časa navzoče ograde znanosti, zagledane $\mathrm{v}$ očiščene kategorije, ulovljive entitete in kristalno jasne segmentacije. ${ }^{3}$ Gre za izjemno pomembno vprašanje, o katerem nekoliko več v nadaljevanju.

\section{Prikrita simbioza: med nami in 'Drugimi'}

Čeprav se identiteta spretno izmuzne trdnim definicijami, lahko gotovo trdimo, da je nacionalna identiteta specifična forma kolektivne identitete, ki omogoča posamezniku orientacijo v prostoru in času. Gre pravzaprav, kakor je zapisal Connor (1978), za »občutje pripadnosti« (po Triandafyllidou, 1998, 595) naciji oziroma narodu, ali če uporabimo znano Andersonovo skovanko, zamišljeni oz. predstavni skupnosti. Pa vendar identiteta obstaja zgolj v kontrastu, zato nepreklicno zahteva prostore drugačnosti in opozicijski protipol - 'Drugega'. Ta je vselej reduciran na obliko, ki ustreza ustvarjalcu, saj je ustvarjanje 'Drugega' nujen del lastnega prepoznavanja (Rapport in Overing, 2004, 12). Glede na dejstvo, da so tako imenovane nacionalne države dominantna oblika družbene organizacije sodobnega sveta, se nacionalna identiteta ustvarja na podlagi prepričanja o obstoju

3 Nekateri si pod krinko svojega akademskega naziva dovolijo razširjanje vrste sovražnih stereotipov, ki potiskajo posameznike v imaginarne kolektivitete. Ko so dr. Andreju Capudru v oddaji Omizje: Nestrpnost do verujočih? sogovorniki očitali, da z etnocentrističnih stališč karakterizira muslimane in da nikakor ne gre za pristop, ki vodi k dialogu, se je ta hitro ubranil z odgovorom, da četudi njegov diskurz ni dialoški, "je pa analitičen pristop znanstvenika « (RTV SLO 2004). 
'Drugih' in drugačnih, (zlasti sosednjih) nacij oziroma narodov. ${ }^{4}$ Razparceliranost svetovne oble na t. i. nacionalne države se zdi namreč povsem naravna in tudi večna svetovna ureditev, globalizacijskemu in transnacionalnemu hiperdifuzionizmu navkljub. Nacionalna identiteta je torej posledica klasifikacije oziroma kategorizacije sveta in tu seveda ne gre za nevtralen in nedolžen prijem, kar potrjuje že sam termin, ki izhaja iz grškega kathegoresthai, kar pomeni javno obtožiti (Bourdieu, 2003, 90). Seveda pa »identiteta sebstva ali 'drugega' ... še zdaleč ni nekaj statičnega, temveč močno obdelan historični, družbeni, intelektualni in politični proces, ki teče kot boj, v katerega so vključeni posamezniki in institucije v vseh družbah« (Said, 1996, 408).

'Drugi' so tako dejansko spremenljiv in gibljiv pojav, saj je nadevanje etikete 'drugosti' odvisno od trenutnih želja in potreb ustvarjalcev kategorije in situacije, v kateri se ti nahajajo. Zato se kategorije spreminjajo, reinterpretirajo, krčijo in razširjajo ter prilagajajo sodobnim težnjam in interesom posameznika in skupnosti. Ideološki aparati države se skozi izdelane strategije vseskozi trudijo doseči nacionalno usklajenost, ko gre za izbor nacionalnega protipola. Meja med 'nami' in 'Drugimi' je enkrat trdna in nepremostljiva, drugič spet izredno prepustna in gibljiva. 'Drugi' lahko v hipu postanejo 'naši', ko se denimo 'prešolajo' v naše priljubljeno nogometno moštvo (glej Giulianotti in Armstrong, 1997). Na primer, Afričani, ki so pogosto tarča sovražnih pogledov ali celo žrtve nestrpnih izpadov in odkritih izbruhov nasilja na francoskih ulicah, so v nogometnih reprezentancah več kot dobrodošli, ko pa se spretno prebijejo skozi nasprotnikovo obrambo in zadenejo med vratnice, postajajo postanejo resnično 'pravi Francozi. Podobno se dogaja na Slovenskem, kjer se je skoraj vsak, čigar priimek se konča s 'pol strešice', srečal s pikrimi komentarji in zbadljivkami na račun svojega 'manka' (nekatere so tovrstni komentarji privedli celo do okenca na upravni enoti), pa vendar pri nogometaših pomanjkljivosti presenetljivo hitro zbledijo ob uspešnih akcijah na igrišču. In tudi v pretresljivi globalni trgovini $\mathrm{z}$ organi, $\mathrm{v}$ kateri posedovanje družbene moči podeljuje pravico do življenja, pogosto barva kože ne pomeni takšne ovire, kot jo za

$4 \mathrm{~Pa}$ vendar »drug, drugačen in tuj je tudi pripadnik iste nacionalne kulture in prav zaradi tega se lahko, ... počutimo v določenih okoljih znotraj naše nacionalne skupnosti kot tujci« (Brumen, 2000, 268). 
mnoge pomeni v drugih življenjskih okoliščinah. Ko potrebuješ pomoč, »srce nima rase« (Scheper-Hughes, 2000), ko pa je treba pomagati, razlike niso le opazne, temveč tudi nevzdržno moteče.

Identitete se torej konstruirajo znotraj posebnih zgodovinskih situacij in na institucionalnih prizoriščih s pomočjo diskurzivnih praks in strategij. So rezultat ustvarjanja razlik in namenskega izključevanja, ne pa neke naravne, dane enotnosti (Hall, 2000, 17). Po Hallu gre torej za »'igro' razlik«, ki ustvarjajo simbolne, imaginarne, a vseeno izredno pomembne meje (Hall, 2000, 17). Fredrik Barth (1969) je v svojem vplivnem, prelomnem in pogosto citiranem delu jasno nakazal bistven pomen meje pri oblikovanju identitet in ne objektivnih ter vsakemu očesu vidnih kulturnih razlik. Tako te niso pomembne same po sebi, saj nimajo pomenov, če jih opazujemo zunaj odnosov, znotraj katerih obstajajo. Torej izvori identitet niso v kulturnih razlikah in izolaciji, temveč v srečevanjih in komunikaciji, v katerih se skozi simbole, razumljive obema skupinama, vzpostavlja in vzdržuje meja. Obstoj meje, ki jo nacionalizem legalizira, utrdi in predstavlja kot naravno razmejitveno črto, omogoča preživetje nacije, saj je »v naših predstavah ... narod omejen, kajti tudi največji med njimi, ki morda združuje milijardo človeških bitij, ima končne, četudi spremenljive meje, za katerimi bivajo drugi narodi ... Celo najbolj mesijanski med nacionalisti ne sanjajo o dnevu, ko bodo vsi pripadniki človeške rase pristopili $\mathrm{k}$ njihovemu narodu « (Anderson, 2003, 16). Takšne aspiracije bi bile v resnici samodestruktivne, kajti brez 'Drugih' ni 'nas', predvsem ne v okrašeni in všečni podobi, $s$ katero se posameznik rad spogleduje in želi identificirati. Civiliziranost zahteva barbarstvo, napredek nazadnjaštvo, superiorni inferiornega. Dihotomije nadrejenosti in podrejenosti ustvarjajo shematiziran črno-beli svet, ki postavlja stvari na primerno in natančno določeno mesto in posamezniku daje jasno in enostavno sliko o svetu, v katerem zato laže zaživi (glej Mach, 1993). Kolektivne karakterizacije, ki zarisujejo meje med opozicijskimi dvojicami, so v resnici karikature realnosti, kar je opazno že, če se le na hitro ozremo okoli sebe in opazujemo naše ali 'zahodnjaške' odnose do posameznih območij, Orienta (Said, 1996), vzhodne Evrope (Wolff, 1994), Balkana (Jezernik, 2004), ki mu zavzeto žugajo s prstom, češ da ni dovolj evropski, da bi sodil v s presežniki okrašeno fiktivno iznajdbo - združeno Evropo -, in niti dovolj moder in zrel za samostojno odločanje. Konstruiranje in vzdrževanje prostorov drugačnosti, kjer domujejo prebivalci vredni 
graje in zgražanja, se dogaja zavoljo podjarmljanja, obenem pa ponuja možnost za dokazovanje stvarnikove večvrednosti; tako je zahodnim državam in družbam pripadla cenjena pozicija vsevednih 'učiteljev življenja'. Vendar gre za absurdno učenje, kajti 'civilizacijska lekcija' ni namenjena prenosu znanja in vednosti, temveč je le izraz in potrjevanje domnevne intelektualne premoči. ${ }^{5}$ To jasno izpričuje tudi pogled v preteklost. Ko si je Balkan, obremenjen z opazkami o svoji 'primitivnosti', nadeval bolj 'evropsko' podobo, so popotniki nejevoljno negodovali in se zgražali nad preobrazbo, 'civilizirani moški' pa so objokovali izgubo svojega romantiziranega bojišča oziroma igrišča, na katerem so izživljali avanturistične fantazije, se uspešno znebili svojih notranjih zavor in s tem zadovoljevali evforično željo po dokazovanju in prelivanju krvi (Goldsworthy, 2002, 30). Znana popotnica Mary Edith Durham je tako kot mnogi pred in za njo obravnavala dežele, označene s pečatom 'neciviliziranosti', v evolucionistični maniri, jih razglašala za otroke, ki morajo odrasti, a vendar je bila ena redkih, ki je trdila, da so zahodnjaški nauki v svoji nepredelani obliki za Balkan nekoristni, kar pa se je nazorno pokazalo skoraj stoletje pozneje ob mednarodnem posredovanju med vojno v Bosni in Hercegovini, ko se je nacionalni projekt par excellance Daytonski mirovni sporazum uveljavil pod vodstvom evropskih in ameriških velesil. Durhamova zapiše: »Da balkanski narodi odrastejo, morajo preiti določene faze razvoja in to morajo storiti sami. Prehitevati dogodke ni smiselno. Paglavca ni mogoče spremeniti v žabo kratko malo s tem, da mu odrežemo rep« (Durham, 1908, 105).

Tendenciozno prikazovanje drugačnosti, lastno tudi nacionalni ideologiji, ki gradi visoke zidove med 'nami' in vedno znova izumljenimi 'Drugimi', utrjuje notranjo kohezivnost in solidarnost nacije. Nacionalizem je vedno okrepljen in aktiviran v času (namišljene) ogroženosti, zatorej skuša nacionalna ideologija s predstavitvijo agresivnih, krvoločnih in nevarnih,

5 Posamezniki, ki trdno verjamejo v lastno superiornost in premoč skupine, ki ji pripadajo, pogosto uporabljajo retoriko $\mathrm{v}$ tipičnem orientalističnem slogu. Ta 'inferiornim' ne dopušča spregovoriti in govori v njihovem imenu. Naj kot poveden primer navedem besede nekdanjega psihiatra in pesnika, zdaj bolj znanega kot vojnega zločinca, Radovana Karadžića, ki odseva tovrstni diskurz, za katerim vselej tičijo interesi. »Mesto Sarajevo je bilo vselej orientirano proti zahodu in celo Muslimani so se počutili bolj Srbi kot Muslimani. Pravzaprav oni to tudi so. Srbi, ki so postali muslimani za časa turške okupacije« (po Antić, 2003, 278). V resnici je nem le tisti, ki ga ne želimo slišati. 
paradoksalno tudi infantilnih 'Drugih' prebuditi in ohraniti kolektivno paranojo. V sodobnosti so se stiki intenzivirali, globalizacija in vsaj navidezna grožnja utapljanja evropskih nacionalnih kultur v skupnih vodah Evropske unije spodbuja občutje neprijetne negotovosti in strahu. Nacionalizem ta strah še zdaj spretno zlorablja, s čimer ustvarja kulturne razlike, ki jih pogosto namenoma spreminja $\mathrm{v}$ probleme.

\section{Za narodov blagor}

Nacionalna država se uspešno legitimizira s statusom varuha kulture (Gellner, 1995, 93), obenem pa skupaj s specializiranimi pomagači določa, kaj pravzaprav sodi v močno idealiziran korpus nacionalne kulture, na podlagi katere naj bi se posamezniki ljudje prepoznali kot del nacionalnega kolektiva. Evropska etnologija se je v 19. stoletju marljivo in pogumno pridružila nacionalnemu projektu in na nekaterih delih globusa še danes, sicer precej bolj subtilno, sledi ustaljenim praksam. O tem nemara priča tudi podatek, da je bilo izpeljanih relativno malo raziskav o tem, kaj je dejansko skupnega na nacionalni ravni. Seveda gre za izredno kompleksen projekt, ki zahteva široko in skoraj neizvedljivo kvantitativno analizo, kar pa za nacionalno navdihnjene raziskovalce nemalokrat ni bila ovira: prav tako jim ni odvzelo poguma in zagnanosti, da ne bi samozavestno spregovorili o nacionalnih karakteristikah in posebnostih. Ti so namreč izsledke raziskav, ki so jih opravili v manjših, zlasti vaških skupnostih, pragmatično posploševali, jih opremili s pečatom lastnega romantičnega zanesenjaštva in s tem na ogled ponudili vselej dvomljive generalizacije, ki so podpirale nacionalne težnje.

Nacionalna kultura ${ }^{6}$ je pravzaprav invencija oziroma konstrukt 18. oziroma 19. stoletja, katere osrednja funkcija je združitev prebivalstva v skla-

6 Ko govorimo o nacionalni kulturi, govorimo o konstruktu, ustvarjenem z natančnim selekcioniranjem, kategoriziranjem, predrugačenjem kulturnih fenomenov in njihovim načrtnim fiksiranjem. Ne gre zgolj za 'izumljanje tradicije', ampak tudi za prilagoditve, reorganizacijo in recikliranje dokumentiranih tradicij (Löfgren, 1989, 12; Rihtman-Auguštin, 2001, 10-11). Mehanizmi ustvarjanja nacionalne kulture zvesto pričajo o njeni oddaljenosti od realnosti, zato lahko govorimo o kanonizirani, uniformirani, idealizirani kulturi, ki ponuja 
dno delujočo, homogeno celoto. Prav v nacionalni kulturi se v najbolj idealni obliki kaže zgrešeno razumevanje široko uporabljenega in zlorabljenega koncepta kulture. ${ }^{7}$ Nacionalna država promovira nacionalno kulturo $\mathrm{v}$ izjemno dodelani kampanji z vrsto ideoloških aparatov, saj nacionalni projekt ne zmore obstati zgolj kot ideološka konstrukcija, temveč mora eksistirati kot del individualnega habitusa in kot kulturna praksa v vsakdanjem življenju (Löfgren, 1989, 23). Izdelana strategija zagotavlja lojalnost državljanov naciji, saj sproža mehanizme identifikacije, kar posameznika privede do tega, da se $\mathrm{v}$ določeni meri nezavedno podredi zahtevam oblasti. Ključno vlogo v tem procesu imajo simboli, ki ohranjajo zavest o skupnosti. Čeprav so ti last kolektiva, nacije, je njihov pomen povsem zaseben, intimen in individualen. Ti namreč omogočajo posamezniku, da občuti in izraža svojo pripadnost družbi ali skupini, tudi državi, s tem da se ne odreče lastni individualnosti. Skupni simboli zagotavljajo vzajemno prepoznavanje in identifikacijo s skupnostjo, hkrati pa zunanjim opazovalcem in nacionalnim voditeljem ponujajo na ogled le zunanji kalup, kar slika zaželeno in lahko obvladljivo podobo enotnosti (glej Cohen, 1994). Njihovo konstantno glasno sklicevanje na unikatnost, avtentičnost in avtohtonost nacionalne kulture implicira odsotnost njenih sprememb in $\mathrm{v}$ resnici zavestno zanemarja dejstvo, da je kultura, prav tako kot identiteta, proces in ne produkt. Posamezniki torej niso pasivni nosilci nacionalne kulture, saj jo sprejmejo, transformirajo, preoblikujejo ter vztrajno soustvarjajo. Tako se iz normativne nacionalne kulture skozi dinamične preobrazbe porajajo neštete različice življenja nacionalne kulture. Zatorej kultura, tudi nacio-

na ogled imaginarno in očem prijetno podobo nacije.

$7 \mathrm{~V}$ pregledni inventuri problematičnosti kulture in na tem utemeljenega negodovanja nad njo je Robert Brightman (1995) poudaril, da se je antropologija v svojih raziskavah pogosto ukvarjala $\mathrm{z}$ reificirano abstrakcijo, torej prosto plavajočo, neodvisno nadorgansko oziroma superorgansko tvorbo, z jasno definiranimi in fiksiranimi mejami, ki jo je bilo mogoče izluščiti in opazovati, ne da bi se bilo treba pretirano obremenjevali s pisanim svetom posameznikov. S tem so etnologi in antropologi povsem prezrli pomen individualnosti, s čimer so individuumom odvzeli možnosti samostojnega izbiranja in improvizacije. Samosvojega posameznika so namreč kratko malo zreducirali na vlogo zvestega in vdanega izvršitelja strogo določenih in večnih zakonov 'pravnega reda' oziroma kulture (Brightman, 1995, 513). Po tej logiki je kultura živela povsem neodvisno in samosvoje življenje. Spoznanje, da »kulture niso živa bitja« (Hannerz, 1996, 69), je močno zamajalo kredibilnost dotedanjega razumevanja kulture in koncepta nasploh. 
nalna, ni prisilni jopič in je ni mogoče kratko malo vsiliti v njeni idealni, stereotipni obliki. 'Naše' torej nikakor ni nujno tudi 'moje'.

Prevlada forme nad substanco je dolgo označevala zanimanje humanistov in družboslovcev in s tem pomembno, a prikrito podpirala nacionalno ideologijo. Zdaj je povsem jasno, da ni mogoče spregledati udeležbe pesnikov, pisateljev, zgodovinarjev, etnologov, folkloristov in drugih intelektualcev v procesu stvaritve nacionalne kulture. Nacionalistični intelektualci 19. stoletja in njihovi nasledniki, ki delujejo še zdaj v mnogih 'periferijah' in 'centrih' sveta, so imeli in imajo nedvomno bolj politične kot pa akademske cilje. Zato je kritični poseg v preteklost etnološkega in antropološkega delovanja, ki se ga zagnano loteva na videz zgolj izrazito destruktivno naravnani postmodernizem, neizogibno početje.

$\mathrm{V}$ zadnjih tridesetih letih se je tudi v etnologiji in kulturni antropologiji pojavilo mnogo del o nacionalizmu (Eriksen, 1993; Muršič 1997: 230), ${ }^{8}$ ki so spodbudila poglobljeno razmišljanje in raziskovanje nacije, nacionalne identitete in kulture. Prvi poskusi odkrivanja kompleksnih fenomenov so bili usklajeni $\mathrm{z}$ obstoječim prepričanjem o znanstvenikovi nepristranskosti, zato so v svojih raziskavah tudi etnologi in kulturni antropologi skušali 'odvreči’ svoja nacionalna občutja (Carmichael, 1999, 126; Okely, 1996). Raziskovalci so se predolgo ponašali s statusom 'univerzalnega tujca', ki naj bi ga odlikovala sposobnost preseganja upravnih in kulturnih meja in ločnic. Zadnja desetletja 20. stoletja pa so nas brezčutno postavila nazaj na trdna tla in s tem opozorila na utopije, v katerih smo predolgo živeli. Zdaj vemo, da biti pripadnik nekega naroda, biti torej Slovenec(ka), Šved(inja), Madžar(ka), Iračan(ka) ni prav nikoli nevtralno dejstvo. Navsezadnje je »edini pravi nenacionalist oseba, ki nima države, ki ne poseduje potnega lista in ki je odvrgla vse privilegije državljanstva« (Carmichal, 1999, 135). Dejstvo, da državljanstvo prinaša vrsto koristi in 'se nam splača', je razumljivo predvsem tistim, ki so v nekem obdobju svojega življenja obtičali v vmesni fazi, torej ko so se znašli v ujetništvu 'nedržavljanstva' in se gnetli v čakalnici za potni list ter pravice in tudi svobodo, ki ga ta prinaša. Zato lastne nacije nikoli ne

8 Nacionalizmu in obravnavi nacionalnih identitet so se morebiti najbolj posvečali antropologi, ki so raziskovali življenje in identifikacijske procese v republikah nekdanje Jugoslavije (glej Bax, 1995; Bringa, 1995; Jansen, 2005; Kolind, 2002; Lockwood, 1975; Sorabji, 1989). 
zmoremo opazovati s povsem neobremenjene pozicije. Govoriti o njej zgolj površno in deskriptivno je torej docela nemogoče. Kajti »še tako nevtralen opis že umešča samega opisovalca in je obenem poseg v opisani predmet", torej "ni je distance, primerne razdalje, ki bi lahko govorca postavljala na varno, denimo v zavetje družboslovnih znanosti in raziskovanja (Dolar, 2003, 22). Povsem samoumevno je, da nihče ne živi v popolni izolaciji in da nihče ne ostane povsem nedotaknjen od zunanjih vplivov. Prav zato preseneča, da so se prav etnologi in kulturni antropologi, ki so bili v najbolj 'pristnem stiku' z življenjem, znotraj katerega so previdno zasledovali odtise okolja, kulture in družbe na posameznikih, spregledovali dejanskost lastne pozicije. $\mathrm{V}$ dobi nacionalnih držav se vplivi nacionalnih stremljenj kažejo tako na raziskovalcih kot tudi na njihovih raziskavah. Država skuša $\mathrm{z}$ različnimi prijemi usmerjati raziskovanje, med drugim tudi skozi visoko izobraževanje in podeljevanje naslovov, na kar je argumentirano opozoril Pierre Bourdieu (2003). Pa ne gre zgolj za vplive na znanstvenike, intelektualce, temveč tudi na celotno raziskovalno polje. Humanisti so se namreč vse prepogosto omejevali na razpredalčkane raziskovalne teme (Said, 1996, 143). Osredotočali so se zlasti na enote, sinhrono delujoče kolektive, v resnici zgolj na celoto skupnosti, ki je v marsičem odsevala ureditev, kakršno je promovirala nacionalna država. Tovrstne podobe so bile večinoma produkt usmerjane percepcije in ne realnosti. Privilegiranje kolektivnega, seveda na račun individuuma, je nedvomno koristilo nacionalni ideologiji, ki ljubi enotnost kolektivitete in $\mathrm{v}$ svojem besednjaku predstavlja nacijo kot skladno misleč in delujoč organizem. Kajti, kot je bilo že poudarjeno, proizvajanje in vcepljanje nacionalne identitete je pravzaprav politični poskus omejitve individualnosti in akcija vsiljevanja družbene homogenosti (Cohen, 1994, 157). Tudi antropologija se je občasno močno približala tistemu, kar je sočasno in seveda argumentirano grajala, se pravi vselej nevarnemu in zavajajočemu simplificiranju, ki vselej potuje skupaj s stereotipizacijo. Posluževala se je generaliziranja v docela analitične kolektive, kot so plemena, kaste, etnične skupnosti, narodi in nacije, ki je pravzaprav zelo surov način kategorizacije, katere neprimernost smo izkusili vsi mi na lastni koži, ko so nas umestili zgolj v imaginarne kategorije, znotraj katerih se unikatna oseba $\mathrm{z}$ imenom in priimkom prelevi $\mathrm{v}$ eno izmed številk $\mathrm{v}$ enako označeni množici (Cohen, 1994). 
Tovrstna naravnanost je bila vsekakor narekovana ne le z izrazito željo raziskovalcev po razumevanju in ureditvi sveta, temveč nedvomno tudi s koncepcijo sveta, v kateri živimo - dobo t. i. nacionalnih držav. Monotono podobo preučevanega kolektiva pa je še dodatno utrjevala in potrjevala etnološka in antropološka obsesivnost z mejami med 'kulturami,', na kar opozarja tudi Barth, ki je negodoval nad pretirano in neprimerno rabo koncepta, ki ga je sam na velika vrata vpeljal v vedo. Ugotavlja, da je bila »'meja' ... naš koncept, ki je bil ustvarjen zato, da služi našim analitičnim potrebam« (Barth, 2000, 34), zato smo jo včasih, meni, videli tudi tam, kjer je ni bilo. In prav s konstrukcijo nacionalne kulture, ki naj bi bila edinstvena, 'avtohtona', 'avtentična' in torej zgolj naša, se je evropska etnologija aktivno udeležila projekta zarisovanja meja (Löfgren, 1989). Z raziskavami kulture, za katero je veljalo, da nikakor ne zmore segati čez meje, čez začrtane okvire, je ta $\mathrm{v}$ svoji preteklosti zanemarila obstoj množice malenkosti in trivialnosti, ki v resnici to niti niso. Po splošnem prepričanju in v dobro zakoreninjeni etnološki tradiciji je denimo »slovenska identiteta za Slovenca ... ropotarnica stereotipov in puhlic o slovenskosti« (Vogrinc, 2003, 41), seveda natančno izbranih, vzdrževanih in legitimiziranih. Do nedavnega so bili do 'nacionalnih trivialnosti' precej bolj pozorni pisatelji kot etnologi in kulturni antropologi, a se tudi ti v zadnjih desetletjih obračajo proč od (preučevanja) standardnega repertoarja nacionalne kulture oz. reificiranih segmentov kulture - nacionalnih noš, hrane, glasbe, plesov, šeg ..., ki pa so, kakor opozarja Tim Edensor (2002), le del kulturne matrice, ki vzdržuje nacijo.

\section{S kung-fujem nad tiranijo nacionalizma}

Miljenko Jergović, nedvomno eden najbolj pronicljivih in dojemljivih opazovalcev (preteklega) življenja v Bosni in Hercegovini, je pesnik in pi-

9 Če vzamemo za primer raziskave migrantov, so etnološko in antropološko pozornost sprva pritegnile zlasti razlike med 'prišleki' in pa 'lokalnim prebivalstvom'. V zadnjih letih se to nekoliko spreminja. Talja Blokland (2002) denimo zatrjuje, da je med Turkinjami in Nizozemkami v eni izmed sosesk na Nizozemskem moč izslediti precej več podobnosti kot razlik. Opozarja, da so Nizozemke enako 'neintegrirane' (gre za besedo, ki v sodobnosti postaja skorajda psovka) v mainstrimovsko družbo kot Turkinje. Kljub temu pa Nizozemke niso nikoli podvržene glasni kritiki zaradi svoje 'neintegracije'. 
satelj, ki smelo presega klišejsko formo, ko gre za nacionalno kulturo in tudi identiteto. Njegovi sprehodi skozi življenja in spomine na otroštvo $\mathrm{v}$ Sarajevu, ki jih bogati s priložnostnimi izvirnimi analizami, slikajo povsem drugačno realnost, kot jo je mogoče uzreti ob prebiranju dosegljivih etnoloških/antropoloških obravnav. Jergović spretno in $\mathrm{z}$ izjemnim občutkom za detajle opozarja na delčke žive nacionalne kulture, ki ne bi smeli uiti obzorju etnologa in kulturnega antropologa. V enem svojih tekstov obravnava 'bosansko-hercegovskega heroja', ki mu ni bila dodeljena pozicija znotraj nacionalnega kalupa: »Večina mladeničev, vojnih herojev, tragičnih likov ali pa zločincev, ki so svojo mladost žrtvovali za svobodo, ki je na koncu ni dobil nihče, za Zmaja od Bosne, Mehmeda El Fatiha, bana Jelačića, kralja Zvonimira, Karađorđa in Dušana Silnega so izvedli le malo prej, preden je nastopil njihov čas za umiranje. In kdo ve, kako so si sploh predstavljali te slavne like iz splošne oziroma nacionalne zgodovine, kaj so o njih izvedeli in koliko so se lahko poistovetili z njihovimi dosežki in zločini. ... Dejstvo je, da so več vedeli in da jim je več pomenil lik in delo Brucea Leeja. ... Bruce Lee je v resnici kulturna dediščina Bosne in Hercegovine. ... Navzoč je bil povsod, v vsaki šoli in razredu in v srcu vsakega dečka, ki je verjel, da se $\mathrm{s}$ trojnim saltom in s serijo desetih udarcev $\mathrm{v}$ sekundi lahko razrešijo vsi problemi; in tistih, ki so v to verjeli, je bilo veliko, mogoče celo več, kot jih je kadarkoli verjelo v nekega drugega čudodelnika. ... Ne samo da je bil Bruce Lee junak njihovega otroštva, za mnoge je ostal edina figura kulturne identitete, edino, kar jih je naredilo pripadnika določenega jezika in kulture« (Jergović, 2003). Katerikoli zvesti nacionalist, predan vernik v svetost 'nacionalne čistosti', ki jih na bosansko-hercegovskem prostoru danes ne primanjkuje, bi se ob prebiranju teh vrstic zgrozil in nemudoma stopil $\mathrm{v}$ bran svojemu jeziku, religiji, identiteti ali pač kulturi, v katero Bruce Lee po vseh pravilih nacionalno zamejenega razmišljanja ne more soditi - po njihovem niti ne gre za pripadnika 'našega ljudstva', ta se ni niti rodil na 'domači zemlji', niti ne uteleša 'duha nacije', skratka ne izpolnjuje temeljnih meril za članstvo v nacionalni kulturi.

Od nacionalizma je nespametno pričakovati, da se bo odrekel zavestnemu in vztrajnemu zarisovanju razmejitvenih črt, v Republiki Bosni in Hercegovini pa je ta proces $\mathrm{v}$ zadnjem desetletju moč nazorno opazovati v vseh sferah življenja, kjer se dogaja velika čistka in kjer se pod leporečjem o 
ohranjanju nacionalne identitete skrivajo sovraštvo, zagrenjenost, fobije in nenasitni politični interesi.

Bruce Lee kot del popularne kulture, ki s prihodom in udomačitvijo pridobiva posebno lokalno preobleko in tako postaja neodtujljiv del živete kulture, povezuje vrsto generacij, ki so odraščale v Bosni in Hercegovini; od Jergovića, rojenega ob koncu šestdesetih let 20. stoletja, do dečkov, ki se še danes igrajo $\mathrm{z}$ improviziranimi nunchakami. Marsikdo se še dobro spominja hudovanja in nerganja mater, ko so ugotavljale, da so se ročaji metel skrivnostno in vztrajno krajšali. Filmski junak, mojster borilnih veščin v bosansko-hercegovskem okviru nima motečega nacionalnega predznaka. Prav ta zdaj ponuja povod za dodatne spore, ki jih spodbudi zgolj omemba Ive Andrića ali Meše Selimovića, pisateljev, za lastništvo katerih potekajo ostri besedni dvoboji. Zato ne preseneča, da so nasprotniki razmejevanj združeni v nevladno organizacijo Urban Movement ${ }^{10}$ sprožili odmevno spodbudo za postavitev spomenika Bruceu Leeju kot edinemu skupnemu bosansko-hercegovskemu junaku. Prvi korak so storili že 20. julija 2003 $\mathrm{z}$ organizacijo javne tribune $\mathrm{z}$ naslovom »Spomenik Bruceu Leeju, ja in zakaj?«; ideja pa se je prelevila v dejanja več kot dve leti kasneje, ko so 26. novembra 2005 v okviru projekta De/konstrukcija spomenikov Sarajevskega Centra za sodobno umetnost (ki si je za cilj zastavil preizpraševanje nekdanjih in zdajšnjih sprevrnjenih zavesti ter njihovih javnih manifestacij (internetna stran www.scca.ba/dekonstrukcija/b_main.htm)) v Mostarju, mestu, ki ga ne deli zgolj reka, odkrili spomenik filmski zvezde (slik. 1). Izbor Mostarja torej nikakor ni naključen. Za Nina Raspudića, pobudnika akcije, je Bruce Lee zaradi svoje hibridne identitete in vsesplošne priljubljenosti simbolni most med Zahodom in Vzhodom, ${ }^{11}$ zato zagotavlja, da v

10 Gibanje Urban Movement Mostar je nastalo leta 1999. Združuje prebivalce Mostarja (zlasti študente, intelektualce in upokojence) ter tiste, ki so pred vojno živeli v tem hercegovskem mestu. Zavzemajo se za razvoj kritične misli in zavračanje nacionalnih mitologij. Postavitev spomenika Bruceu Leeju je ena izmed umetniške akcij, s katero skušajo preprečiti uničevanje javnih urbanih prostorov (http:www.scca.ba/dekonstrukcija/b_main.htm). Nino Raspudić (2005) namreč povojni urbanizem razume kot "nadaljevanje vojne z drugačnimi sredstvi«, saj vsaka stran, tako hrvaška kot bošnjaška, izvaja arhitekturno čistko, in sicer si z gradnjo sakralnih objektov ter izpostavljanjem verskih simbolov skuša dokončno prisvojiti prostor, s tem razdeliti Mostar ter izbrisati multikulturno dediščino mesta.

11 Naj dodam, da večji del Bošnjakov in tistih, ki se definirajo za Bosance in Hercegovce, vztra- 
tem primeru nikakor ne gre za čaščenje igralca, kakor spomenik razumejo mnogi in kakor je nemara mogoče razumeti spomenik Leeju, ki so ga dan pozneje odkrili v Hong Kongu (slik. 2), kajti ideja o postavitvi spomenika Leeju v Mostarju se je »rodila iz globoke bolečine in bede nesrečnega mesta« (Raspudić, 2005).

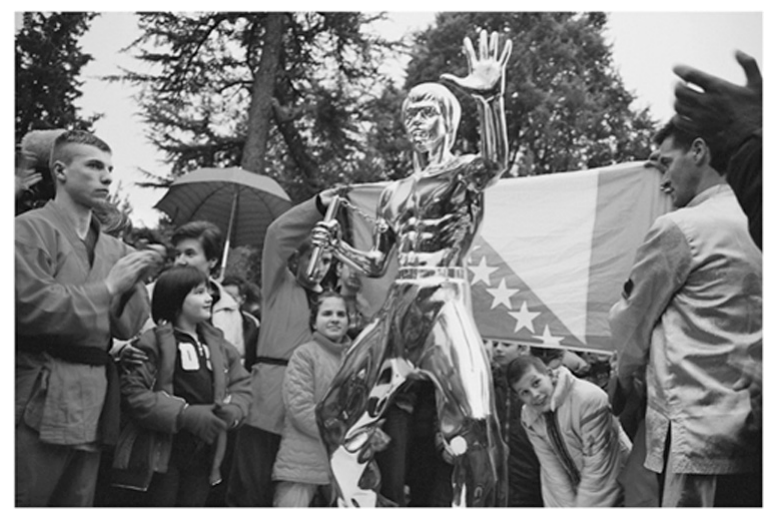

slik. 1: Slovesnost ob odkritju spomenika Bruceu Leeju v Mostarju vir: http://www.scca.ba/deconstruction/e_partnerski_projekti.htm

Kulturni okvir je tisti, ki odreja in omogoča svojevrstne interpretacije in rabe kulturnih fenomenov (Edensor, 2002, 14-15). Medtem ko so v ameriškem okviru, zlasti pa skozi oči migrantskih skupnosti iz Azije filmi Bruca Leeja, kakor ugotavlja Hsiung-ping Chiao, gledalcem ponujali antikolonialistična in nacionalna sporočila, posledično pa so Leeja oboževalci dojemali kot zagovornika in borca za ohranitev nacionalnih identitet (Shu pa dodaja, da se je Lee zelo eksplicitno identificiral s kitajskim narodom, kar je vzrok, da ni nikoli dosegel popularnosti, kakršno je za njim užival nacionalno nevtralnejši Jackie Chan (Shu, 2003, 54)) (po Shu, 2003, 52), je jasno, da spomenik Bruce Leeju v Mostarju kaže drugačno percepcijo. Postavitev spomenika v bosansko-hercegovskem okviru pomeni manifestativni odpor objestnemu in preglasnemu nacionalizmu, ki ne priznava skupne

ja, da ni mogoče govoriti o Vzhodnem in Zahodnem Mostarju. Hkrati pa zanikajo tudi daytonsko delitev Bosne in Hercegovine na Federacijo Bosno in Hercegovino ter Republiko Srbsko. 
bosansko-hercegovske dediščine. ${ }^{12}$ Leejev spomenik pravzaprav opozarja na del skupne bosansko-hercegovske identitete, del identitete, zaradi katere »nihče ni bil prisiljen ubijati in nihče ni bil ubit«. Zato v Urban Movementu menijo, da je Bruce Lee primerno sidrišče identitete, vendar nove, lokalne, meščanske identitete prebivalcev Mostarja (Raspudić, 2005).

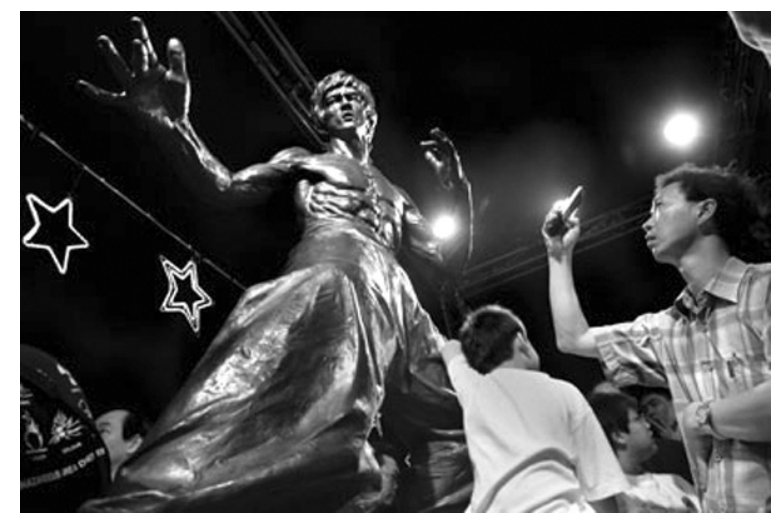

slik. 2: Spomenik Bruceu Leeju v Hong Kongu vir: http://www.abc.net.au/news/newsitems/200511/s1517802.htm

Leejev spomenik je zatorej mogoče razumeti tudi kot hudomušno ironizacijo bosansko-hercegovske sodobnosti, kajti v skladu s postmodernističnimi smernicami spomenik združuje 'visoko' oz. uradno kulturo in 'nizko' popularno - čeprav je jasno, da je tako jasno začrtana bipolarna delitev precej dvomljiva -, tako da zastavlja ključna vprašanja o tem, komu pravzaprav dandanes postavljamo spomenike, kakšna so merila selekcije in zakaj si prav izbrani privilegiranci zaslužijo delček javnega prostora in poglede mimoidočih (Raspudić, 2005). Hkrati pa seveda ni mogoče ubežati premisleku o tem, kdo so tisti, ki odločajo o izbrancih. V Republiki Bosni in Hercegovini so po nedavni vojni na ulicah in trgih mest in vasi odkrivali

$12 \mathrm{Tu}$ je pomembno opozoriti tudi na fenomen Bore Leeja, ki je sprožil zanimanje za filmsko ustvarjanje na Hrvaškem, kjer so njegovi amaterski kung-fu filmi doživeli zavidljiv uspeh. »Bore Lee, s pravim imenom Boris Ivković, prihaja iz Sinja, majhnega mesta trideset kilometrov severno od Splita, iz mesta, ki v hrvaški javnosti velja za rigidno, desničarsko in tradicionalno mesto « (Sertić, 2005, 101) in kjer posamezniki iščejo izhode iz z nacionalizmom preobremenjenega okolja. 
spomenike mitologiziranim nacionalnim junakom in vojnim zločincem, ki so nenadoma postali heroji zavoljo svojih nečastnih dejanj. Postavljanje tovrstnih spomenikov je vsekakor razburkalo medijske vode in prililo olja na ogenj, kar je nacionalistično nastrojenim oblastnikom ponudilo dodatno priložnost za zagnano nabiranje volilnih glasov. Danes, ko se nacionalna realnost in nacionalne resnice izpostavljajo kot edine in večne, spomenik Bruceu Leeju opominja tudi na dejstvo, da so vsi heroji le začasni in da je njihova slava minljiva (Raspudić, 2005). To dejstvo pa tistim, ki ne najdejo svojega prostora v sodobni bosansko-hercegovski družbi, ponuja upanje, da prihaja drugačna, morebiti boljša prihodnost.

Pri kompleksnem projektu grajenja nacije se nenehno vsiljujejo izbrane 'kulturne sestavine', ki naj ločujejo, kar pa mnogokrat pomeni brezbrižno brisanje in nadomeščanje tistega, kar ima $\mathrm{v}$ resnici pomen za posameznika. Jergovićeve besede in $\mathrm{v}$ zlato preobleko odeti kip sredi parka sproža zanimivo vprašanje o povezavi med nacionalno in popularno kulturo - se pravi kulturo, ki stavi na nacionalno mejo, in kulturo, ki jo poskuša in pogosto uspeva preseči. To se zdi pomembno zlasti v dobi transnacionalnalnih in globalnih prepletanj, v kateri sledimo paradoksalni situaciji, ko se simultano odvijajo procesi kulturne homogenizacije in kulturne heterogenizacije (Muršič, 2002). Globalni in transnacionalni tokovi ne izključujejo nacionalne interpelacije, saj ima ta dvojne in nasprotujoče si učinke: lahko namreč zmanjša pomen nacionalne identitete ali pa jo $\mathrm{z}$ novodobnimi priročnimi orodji krepi.

Bruce Lee je sicer produkt in lastnina globalnega sveta, vendar pa je $\mathrm{v}$ bosansko-hercegovskem primeru zaznamovan $\mathrm{z}$ lokalnim pečatom, saj je uporabljen ne le kot sredstvo, ki naj bi utišalo ekskluzivistične nacionalizme, temveč tudi kot vezni člen v poskusih 'oživljanja' bosansko-hercegovske identitete. Zatorej pri obravnavi konstruiranja nacionalnih kultur, da bi se sprožili identifikacijski procesi, kot poudarja Edensor, ni mogoče mimo dejstva, da v sodobnem svetu poleg zgodovinarjev, folkloristov, etnologov in pisateljev vlogo 'koproducentov' nacionalnih identitet igrajo tudi pop zvezdniki, oglaševalci, igralci, športni junaki, filmski producenti ... (Edensor, 2002, 9). Popularna kultura je ravno zaradi svoje prožnosti prilagodljiva za (iz)rabo, tudi ko gre za vprašanja nacionalnosti. 
Kakorkoli že, Jergović in Urban Movement so z zdravo mero humorja, ki se prepleta $\mathrm{z}$ bolečino, dregnili v najobčutljivejšo rano lokalnih nacionalnih gurujev $\mathrm{z}$ vseh treh strani in s tem $\mathrm{v}$ resnici izrazili, da ne zmorejo in ne želijo pogoltniti svojih dvomov in zadržkov, ko premišljujejo o smiselnosti in upravičenosti delitve bosansko-hercegovske kulture na način, kot se to počne. Njihovo mnenje odseva prepričanje posameznikov, ki se zavedajo frustrirajoče bosansko-hercegovske realnosti, saj so sami živeli v precej drugačni Bosni in Hercegovini, kjer 'veliki koncepti' aktualne delitve niso bili zanimivi. Če si dovolim poseg v avtobiografijo ${ }^{13}$ ter prikličem spomine na lastno otroštvo in odraščanje v Sarajevu, ki so tako kot spomini nasploh obremenjeni z nostalgijo in retrospektivnimi popravki, je bila v Sarajevu za generacijo, rojeno konec sedemdesetih in $\mathrm{v}$ začetku osemdesetih let, opazna razlika prav na tej, 'trivialni' in pogosto zanemarjeni ravni. Razlika med sosedi in prijatelji je zame osebno obstajala zlasti v praznovanju različnih praznikov, bajrama in predvsem velike noči (saj se je božič spretno prelival v pričakovanje novega leta); pravzaprav, če sem iskrena, so bili za nas otroke ene izmed mnogih sarajevskih četrti pomembni predvsem interesi - baklave in pirhi, slaščice in igra. ${ }^{14} \mathrm{~V}$ adolescenci pa sta se središčna delitev in temelj identitete naslanjala na pripadnost oboževalcem deške plešoče skupine The New Kids on the Block ali rockerske senzacije Guns N'Roses. Tudi zdaj je mogoče, kljub družbeni prežetosti z nacionalizmom, opazovati razmejitveno črto med oboževalci prsatih in razgaljenih turbo-folk zabavljačic in nostalgiki, ki posegajo za starimi 'komadi' Azre, Bijelog dugmeta, Haustora, Indexa, Đorđeta Balaševića, EKV-ja ... Pa vendar so za posameznike, ki pripadajo zdaj odraščajočim generacijam, zidovi na razmejitvenih črtah precej bolj samoumevni. O tem priča tudi uničenje spomenika Brucu Leeju, ki je le nekaj ur po postavitvi doživel napad mladeničev, ki so kungfu mojstru iz rok iztrgali nunchakue, nato so ga $\mathrm{z}$ grafitom pospravili $\mathrm{v}$ predal, označen $z$ et(n)iketo 'Žućo Lee', in ga nenazadnje $z$ udarci spravili na tla (slik. 3).

13 Avtobiografskim zgodbam je v drugi polovici 20. stoletja sodobna antropologija priznala vlogo pomembnega epistemološkega orodja, ne da bi njihovim avtorjem, kakor je bilo to dotlej v navadi, očitala egocentiričnost in narcizem (glej Okely in Callaway, 1992).

$14 \mathrm{~V}$ pogovoru z nekdanjimi sosedi in prijatelji iz otroštva sem ugotavljala, da nas večina razmišlja podobno. 


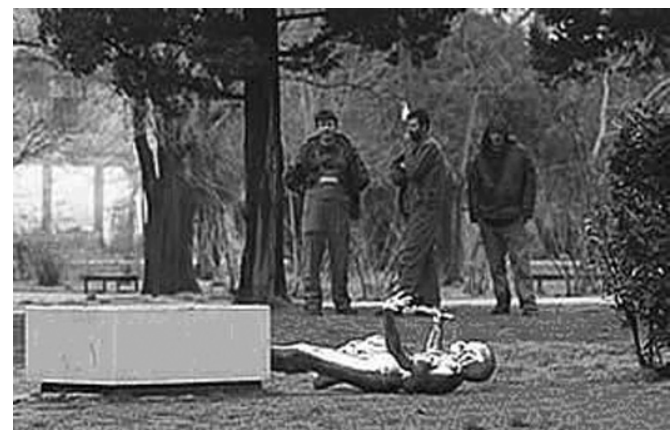

slik. 3: Poškodovani spomenik pred odstranitvijo

vir: http://www.24sata.info/portal/pregled.php?ArtID=16894

Prevlada nacionalne identitete nad drugimi identitetami je stvar konteksta. In nenazadnje ima tudi nacionalna identiteta svojevrstne preobleke. »Vsaka identiteta je krhek rezultat nasprotujočih si procesov prilaščanja in razlaščanja, inventivnosti ali prevzemanja novosti in ohranjanja tradicij« (Muršič, 2002, 8). In čeprav je jasno, da so med oboroženim spopadom nacionalne identitete prevladale, pa ne zgolj zaradi patriotizma, ljubezni do nacije, občutja ogroženosti, ampak zlasti zaradi zaščite družine, prijateljev, sorodnikov, znancev in tudi prostorov, prežetih s spomini (tudi kinodvoran, v katerih so predvajali vratolomne kung-fu vragolije Malega Zmaja), ko so bili tarča napada zgolj zaradi nacionalnega oštevilčenja in ne zaradi tega, kar v resnici so, je na obeh straneh bojne linije - presenetljivo - vojaško energijo s svojimi udarnimi narodnjaškimi hiti dvigovala Arkanova žena - Svetlana Ražnjatović - Ceca.

\section{Zakaj slediti trendu?}

Kljub temu, da so vprašanja identitete sprva zanimala predvsem tiste etnologe oz. antropologe, ki so se ukvarjali $\mathrm{z}$ neevropskimi kulturami, » $\mathrm{s}(\mathrm{m}) \mathrm{o}$ se $\mathrm{z}$ identitetami v naši stroki po svoje ukvarjali prav vsi« (Brumen, 2000, 71). V sodobne razprave o identifikacijskih procesih, ki razkrivajo zmote starejših esencialističnih pojmovanj etničnega, nacionalnega itd., se je vključil tudi Homi Bhabha (1996), ki je transparentno opozoril na hibridno naravo identitet. Te se namreč v sodobnem svetu porajajo in reproduci- 
rajo v prostorih 'vmesnosti', kjer se srečujejo, prepletajo in zapletajo različni kulturni tokovi in kjer globalna produkcija doživlja svojevrstne lokalne adaptacije. Tako smo priča »sodobnemu križanju nekoč nezdružljivih faset identitet« (Murišič, 1997, 229), kar razkriva dinamičnosti, situacijskost in neskončno fluidnost identitet. Hkrati pa opazujmo tudi izjemno pestrost globalne ponudbe, v kateri tičijo potencialna identifikacijska sidrišča. Gre pravzaprav za 'surovine', ki se skozi identitetne procese vseskozi redefinirajo, rekonstruirajo ter pridobivajo svojevrstne pomene.

Primer bosansko-hercegovskega prilaščanja velike kung-fu zvezde Brucea Leeja kaže, kako v okoliščinah, kjer dominira ekskluzivistična nacionalna hegemonija, popularnokulturni fenomen postaja argument in orodje v antinacionalističnem diskurzu, ter obenem tudi sidrišče identitete, in sicer tako lokalne - mostarske, kot tudi državljanske - bosansko-hercegovske.

$\mathrm{V}$ ospredju antropoloških raziskav so bile dolgo kulture, predstavljene kot hipotetični izolati, ki so posedovale svoj prostor na zemeljski obli. S tem smo se mnogokrat znašli v skrajno neprijetni situaciji, ko smo $s$ fokusiranjem zlasti na etnične, kasneje tudi nacionalne identitete, naturalizirali ideologije, tudi nacionalizem in ga nemalokrat izpostavljali kot najpomembnejši temelj identifikacije. Tako smo večkrat potisnili na margine zanimanja druga gibanja in skupnosti, ki so bile ustvarjene na podlagi drugačnih interesov in identitet (Pratt, 2003, 20). Skratka razlogov, zakaj se moramo etnologi in kulturni antropologi podajati še globlje v raziskave identitet, je več. Prvič, gre za odgovornost, saj se je etnologija/antropologija $\mathrm{z}$ vztrajnim obračanjem in konstruiranjem skladno delujočih entitet in nenehnim osredotočanjem na razlike med skupnostmi in ne tudi znotraj njih oddaljila od vprašanja, kako in s kom se posamezniki v različnih okvirih, časih, prostorih in situacijah identificirajo. Pri tem je seveda neizogiben pretres konceptov, preseganje profesionalne lojalnosti do nekaterih paradigem vednosti, kar pomeni drzni dvom o avtoriteti tradicije lastne vede. In drugič zato, ker še vedno premalo poznamo same procese oblikovanja identitete, ki se odvijajo v vozlišču transnacionalnih in globalnih tokov. Skratka odstreti je treba pogled v različne okvire, znotraj katerih se identiteta producira, opazovati, kako ta variira v času, ter kako se prepleta z drugimi obstoječimi identitetami. 
V Bosni in Hercegovini tisti, ki se upirajo reduciranju posameznikove identitete zgolj na nacionalno pripadnost, s pomočjo Brucea Leeja in z nostalgičnimi spomini na predvojno Bosno in Hercegovino, izražajo globoko razočaranje nad trenutno situacijo. Stef Jansen $(2005,108,221-222)$ ugotavlja, da je postjugoslovanski antinacionalistični diskurz (in tu govori predvsem o diskurzivnih strategijah v Zagrebu in Beogradu) tesno povezan z jugonostalgijo, s pomočjo katere ljudje konstruirajo vez s preteklostjo, vendar je ta $\mathrm{v}$ resnici pomembna za prihajajoče dni, kajti odraža željo po boljšem življenju in prijaznejši prihodnosti. Čeprav v Bosni in Hercegovini in v izpostavljenem primeru težko govorimo o jugonostalgiji, ni mogoče mimo dejstva, da se tudi tu spomini izpostavljajo kot strategija upora in oprijemališče identitete. Pomen individuumovega razumevanja preteklosti pri konstruiranju identitete zavzema središčno vlogo predvsem $\mathrm{v}$ raziskavah nacionalizma in nacionalnih identitet. Upoštevanje pomena posameznikovih percepcij prihodnosti v identifikacijskih procesih pa je ostalo skoraj povsem prezrto (Hage, 2003, 10). Pravzaprav gre za nerazdružljivi sferi, kajti »identiteta je kreacija konstantnosti v času, vstop preteklosti v povezavo $\mathrm{z}$ anticipirano prihodnostjo « (Brumen, 2000, 77). Bruce Lee naj bi prinesel boljšo prihodnost Mostarju in Republiki Bosni in Hercegovini. Kajti po mnenju Nina Raspudića (2005) ta simbolizira pravičnost in hibridnost, povezovanje in sobivanje Vzhoda in Zahoda, kar naj bi bila najprimernejša ideologija za življenje v Mostarju v 21. stoletju. Poudarja, da je naloga mladih in Urban Movementa ponovno "zgraditi svoje mesto in ustvariti svoj svet«. Podobna želja se kaže tudi v pesmih bosansko-hercegovskega rapperja, Ede Maajke (Edina Osmića), ki, kot pravi njegova biografija, »uteleša dober duh bosanskega naroda « (http://www.edomaajka.com/biografija/). V pesmi 'A smo sami?' se Edo Maajka sprašuje, če je življenje na drugih planetih podobno življenju na Zemlji. Kljub temu, da ne prejme nobenih odgovorov na nešteta vprašanja, ki si jih zastavlja, ta kristalno jasno odsevajo njegovo globoko razočaranje nad svetom, v katerem živi. Zato pravzaprav sklene, da huje kot na zemeljski obli ne more biti, tako se njegova radovednost, podkrepljena z jezo, prelevi v iskanje boljše prihodnosti: »Ali bodo v prihodnje ponujali vize tujcem? Ali bodo kot begunce sprejemali nas Bosance? Naj me vzamejo prvega, tu nimam nobenega načrta, hiše, stanovanja, življenjskega elana, niti volana, da vozim. Tu mi je nerodno, a pri vas bom prosjačil«. V refrenu pa se nostalgično spominja na predvojne čase, $\mathrm{v}$ katerih se kot identitetna 
sidrišča znova prikažejo heroji popularne kulture, ki so pravzaprav metafora za vrednote, ki jih zastopajo, in zaželeno prihodnost: »Naj nam vrnejo Elvisa, Haseta, Bruce Leeja, in tu imajo silikone, atomsko in CIO. « ${ }^{15}$

Bosansko-hercegovska zgodba o prilaščanju Brucea Leeja nedvomno priča, da etnološke in antropološke raziskave, ki se osredotočajo na identitetne procese, niso le izraz ekstatičnega trendovskega navdušenja, temveč gre pravzaprav za nespregledljiv simptom nuje.

\section{VIRI}

Durham, M. E., The Burden of the Balkans, London, 1908.

http://www.24sata.info/portal/pregled.php?ArtID=16894 (24.3.2006).

http://www.abc.net.au/news/newsitems/200511/s1517802.htm

(24.3.2006).

http://www.edomaajka.com/biografija (1.3.2007).

http:www.scca.ba/dekonstrukcija/b_main.htm (1.3.2007).

Jergović, M., Bruce Lee na KM, 2003, http://www.bhdani.com/default.asp?kat=kol\&broj_id=334\&tekst_ $\mathrm{rb}=24$ (7. junij 2005).

Omizje: Nestrpnost do verujočih?, 28.1.2004, RTV Slovenija.

Raspudić, N., Bruce Lee monument in Mostar, 2005, http://www.policiesforculture.org/administration/upload/bruce_lee_ pfc.pdf (15.3.2006).

$15 »$ Je li imaju u vidu davat vize za strance?

Hoće li primat ko' izbjeglice nas Bosance?

Nek' me prime prvog, ovdje nemam plana, kuće, stana,

životnog elana ni volana da vozim.

Ovdje mi je neugodno, al' kod vas ću da prosim.

Nek' nam vrate Elvisa, Haseta, Bruce Leea,

A evo im silikoni, atomska i CIA.« 


\section{LITERATURA}

Althusser, L., Ideologija in ideološki aparati države, v: Ideologija in estetski učinek: zbornik (ur. Skušek - Močnik, Z.), Ljubljana, 1980, str. 55-110.

Anderson, B., Zamišljene skupnosti: O izvoru in širjenju nacionalizma, Ljubljana, 1998.

Antić, A., Evolucija i uloga tri kompleksa istorijskih mitova u srpskom akademskom i javnom mnjenju u poslednjih deset godina, v: Historijski mitovi na Balkanu (ur. Kamberović, H.), Sarajevo, 2003, str. 259-290.

Barth, F., Introduction, v: Ethnic groups and boundaries. The social organisation of culture difference (ur. Barth, F.), Bergen, 1969, str. 9-38.

Barth, F., Bounderies and connection, v: Signifying identities. Anthropological perspectives on boundaries and contested values (ur. Cohen, A.), London, New York, 2000, str. 17-36.

Baš, A., (ur.), Slovenski etnološki leksikon, Ljubljana, 2004.

Bauman, Z., Intimations of postmodernity, London, New York, 1992.

Bax, M., Medjugorje: Religion, Politics, and Violence in Rural Bosnia, Amsterdam, 1995.

Bhabha, H. K., Culture's In-Between, v: Questions of cultural identity (ur. Hall, S. in P. du Gay), London, Thousand Oaks, Ca., New Delhi, 1996, str. 53-60.

Billig, M., Banal nationalism, London, 1995.

Blokland, T., Peer groups as frames for social identification: Peer-group lives of Turkish-Dutch and native Dutch women in Inner-city neighborhoods, v: Identity in transformation: Postmodernity, postcommunism and globalization (ur. Kempny, M. in Jawlowska, A.), Westport, 2002, str. 153-162.

Bourdieu, P., Sociologija kot politika, Ljubljana, 2003.

Brightman, R., Forget Culture. Replacement, transcendence, relexification, Cultural Anthropology 10(4), (1995), str. 509-546. 
Bringa, T., Being Muslim the Bosnian way: identity and community in a central Bosnian village, Princeton, 1995.

Brumen, B., Sv. Peter in njegovi časi: Socialni spomini, časi in identitete $v$ istrski vasi Sv. Peter, Ljubljana, 2000.

Clifford, J., Introduction: Partial truths, v: Writing culture. The poetics and politics of ethnography (ur. Clifford, J. in Marcus, E.G.), Berkeley, 1986, str. 1-26.

Cohen, A. P., Self consciousness: An alternative anthropology of identity, London, New York, 1994.

Cohen, A. P., The symbolic construction of community, London, New York, 1998.

Cohen, A. P. (ur.), Signifying identities. Anthropological perspectives on boundaries and contested values, London, New York, 2002.

Dolar, M., Slovenska nacionalna identiteta in kultura - navodila za uporabo, v: Nacionalna identiteta in kultura (ur. Pagon, N.), Ljubljana, 2003, str. 21-35.

Edensor, T., National identity, popular culture and everyday life, Oxford, New York, 2002.

Eriksen, T. H., Ethnicity and Nationalism. Anthropological Perspectives, London, Boulder, Colorado, 1993.

Fonda, P., Obmejni psihogrami, v: Nacionalna identiteta in kultura (ur. Pagon, N.), Ljubljana, 2003, str. 109-122.

Giulianotti, R. in Armstrong, G., Introduction: Reclaiming the game - An introduction to the anthropology of football, v: Entering the Field. New perspective on the world football (ur. Giulianotti, R. in Armstrong, G.), Oxford, 1997, str. 1-29.

Goldsworthy, V., Inventon and in(ter)vention: The retoric of balkanization, v: Balkan as metaphor: Between globalization and fragmetation (ur. Bjelić, D. in Savić, O.), Cambridge, London, 2002, str. 25-38.

Hage, G, Against paranoid nationalism: Seraching for hope in shrinking society, Annandale, 2003. 
Hall, S., Who needs 'identity'?, v: Identity: a reader (ur. du Gay, P. in drugi), London, 2000, str. 15-30.

Hannerz, U., Transnational connections. Culture, people, places. London, New York, 1996.

Inda, X. J. in Rosaldo, R., Introduction. A world in motion, v: The anthropology of globalization: a reader (ur. Inda, X. J. in Rosaldo, R.), Oxford, 2002, str. 1-34.

Jansen, S., Antinacionalizam: Etnografija otpora u Beogradu i Zagrebu, Beograd, 2000.

Jenkins, R., Different societies? Different cultures? What are human collectivities?, v: Making sense of collectivity. Ethnicity, nationalism and globalization (ur. Milošević, S. in Haugaard, M.), London, 2002, str. 12-32.

Jezernik, B., Wild Europe: The Balkans in the gaze of Western travellers, London, 2004.

Kalapoš, S. Manifold identity of a Territorial subcultural group from Zagreb, Glasnik SED 36(4), (1996), str. 2-6.

Kempny, M., Introduction: On 'identity', fixity, and change in social theory and social life under globalized conditions, v: Identity in transformation: Postmodernity, postcommunism and globalization (ur. Kempny, M. in Jawlowska, A.), Westport, 2002, str. 1-16.

Kolind, T., Non-ethnic Condemnation in Post-War Stolac: An Ethnographic Case-Study from Bosnia-Herzegovina., v: The Balkans in Focus: Cultural Boundaries in Europe (ur. Resić, S. in Tornquist-Plewa, B.), Lund, 2002, str. 121-136.

Lockwood, W. G., European Moslems: Economy and ethnicity in Western Bosnia. New York, San Francisco, London, 1975.

Löfgren, O., The nationalization of culture, Etnologia Europaea XIX, (1989), str. 5-23.

Löfgren, O., The nationalization of anxiety: A History of border crossings, v: The postnational self. Belonging and identity (ur. Hedentoft, U. in Hjort, M.), Minneapolis, London, 2002, str. 250-274. 
Lovrenović, I., Bosanski Hrvati: Esej o agoniji jedne evropsko-orientalne mikrokulture, Zagreb, 2002.

Mach, Z., Symbols, conflict, and identity: Essays in political anthropology, Albany, 1993.

Muršič, R., »Razkritje krinke«: o lokalno globalnih identifikacijah, Traditiones 26, (1997), str. 223-236.

Muršič, R., Kultura v primežu globalizacijskih procesov in vseprisotne popularne kulture: Izločitev pojma iz strokovnega besednjaka?, Glasnik SED 42(3), (2002), str. 4-10.

Pratt, J. Class, Nation and Identity: The Anthropology of Political Movements, London, 2003.

Okely, J. in Callaway, H. (ur.), Anthropology and autobiography, London, New York, 1992.

Okely, J., Own and other culture, London, New York, 1996.

Rapport, N. in J. Overing, Social and cultural anthropology: The Key Concepts, London, New York, 2004.

Repič, J., Migracijski procesi in konstruiranje ter oblikovanje transnacionalnih skupnosti in identifikacij med argentinskimi priseljenci $v$ Evropi in slovenskimi priseljenci v Argentini: doktorska disertacija. Ljubljana, 2005.

Rihtman-Auguštin, D., Ulice moga grada. Antropologija domaćeg terena, Beograd, 2000.

Rihtman-Auguštin, D., Etnologija i etnomit, Zagreb, 2001.

Said, E., Orientalizem. Zahodnjaški pogledi na Orient, Ljubljana, 1996.

Sertić, O., Fenomen Bore Lee, Časopis za kritiko znanosti, domišljijo in novo antropologijo XXXIII(220), (2005), str. 101-108.

Shu, Y., From Bruce Lee to Jackie Chan: Reading the kung gu film in an American context, Journal of Popular Film and Television 31(2), (2003), str. 50-59.

Smith, A. D., Nacionalni identitet, Beograd, 1998. 
Scheper-Hughes, N., The global traffic in human organs, Current Anthropology 41(2), (2000), str. 191-223.

Sorabji, C., Muslim identity and Islamic faith in Sarajevo: doktorska disertacija, Cambridge, 1989.

Suny, R. G. in Kennedy, M. D. (ur.), Intellectuals and articulation of the nation, Ann Arbor, 1999.

Triandafyllidou, A., National identity and the 'other', Ethnic and Racial Studies 21, (1998), str. 593-612.

Vogrinc, J., Čemu 'nacionalna identiteta' in 'nacionalni interes' v kulturni politiki?, v: Nacionalna identiteta in kultura (ur. Pagon, N.), Ljubljana, 2003, str. 37-51.

Walton, J. in Warren, M. (ur.), Inside the mixed marriages. Accounts of changing attitudes, patterns, and perception of the cross-cultural and interracial marriages, Lanham, 1994.

Wolff, L., Inventing Eastern Europe. The map of civilization on the mind of the enlightenment, Stanford, 1994. 


\section{IDENTITY AS FLEETING FASHION? REVEALING THE BACKGROUND OF POPULARITY THROUGH BOSNIA- HERZEGOVINA'S ADOPTION OF BRUCE LEE}

Keywords: identification processes, (national) identity, construction of Others, national culture, popular culture, the Balkans, Bosnia-Herzegovina, Bruce Lee

\section{Abstract}

This paper reflects on the background to popular research on identification processes in modern ethnology and cultural or social anthropology. By discussing themes closely connected to identity (national and popular culture, and the construction of Others), the author reveals that identity is not merely a redundant trend that researchers recklessly pursue, but that it reflects the need to reveal existing uncertainties and is an attempt to revise errors made to date, as well as lapses of the discipline we work in. The author primarily focuses on national identity and its situational transformations and intertwining with other existing identities. Bosnia-Herzegovina is placed at the center of interest. This theoretically oriented text concludes by analyzing the idea of erecting a monument to Bruce Lee in Mostar, which reveals the full complexity of identity processes around a world marked by intense and unique global and transnational currents 